\title{
Integrated water vapor above Ny Ålesund, Spitsbergen: a multi-sensor intercomparison
}

\author{
M. Pałm ${ }^{1}$, C. Melsheimer ${ }^{1}$, S. Noël ${ }^{1}$, S. Heise ${ }^{2}$, J. Notholt ${ }^{1}$, J. Burrows ${ }^{1}$, and O. Schrems ${ }^{3}$ \\ ${ }^{1}$ Institute of Environmental Physics, Universität Bremen, Germany \\ ${ }^{1}$ Helmholtz Centre Potsdam, GFZ German Research Centre for Geosciences, Potsdam, Germany \\ ${ }^{3}$ Alfred Wegener Institut, Bremerhaven, Germany
}

Received: 2 September 2008 - Published in Atmos. Chem. Phys. Discuss.: 18 December 2008

Revised: 30 November 2009 - Accepted: 19 January 2010 - Published: 3 February 2010

\begin{abstract}
Water vapor is an important constituent of the atmosphere. Because of its abundance and its radiative properties it plays an important role for the radiation budget of the atmosphere and has major influence on weather and climate.

In this work integrated water vapor (IWV) derived from the measurements of three satellite sensors, GOME, SCIAMACHY and AMSU-B, two ground based sensors, a Fourier-transform spectrometer (FTIR), a microwave radiometer for $\mathrm{O}_{3}$ (RAM) and IWV inferred from GPS zenith path delay (ZPD) measurements, are compared to radiosonde measurements above $\mathrm{Ny}$ Ålesund, $79^{\circ} \mathrm{N}$. All six remote sensors exploit different principles and work in different wavelength regions.

All remote sensing instruments reproduce the sonde measurements very well and are highly correlated when compared with the radio-sonde measurements.

The ground-based FTIR shows very little scatter of about $10 \%$. The GPS performs similar to the FTIR at all times except for very low IWV, where the scatter exceeds $50 \%$ of the measured IWV. The other remote sensing instruments show scatter of about 20\% (standard deviation). The ground-based RAM performs similar to the satellite instruments, despite the fact that the retrieval of IWV is just a by-product of this ozone sensor.
\end{abstract}

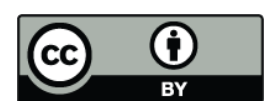

Correspondence to: M. Pałm (mathias@iup.physik.uni-bremen.de)

\section{Introduction}

Water vapor is the most abundant trace gas in the troposphere. Due to its radiative properties it contributes a large part to the atmosphere's radiation budget. It influences the climate due to cloud, ice formation and energy transfer and is responsible for most of the weather. Hence, the integrated water vapor (IWV) is an important factor for short term weather prediction.

Due to the large gradient of the volume mixing ratio (VMR) from the ground to the tropopause (approx. $10000 \mathrm{ppm}$ at the ground to approx. $4 \mathrm{ppm}$ at the tropopause), the measurement of water vapor is a demanding task.

Several techniques are employed to retrieve IWV information as well as profile information from atmospheric measurements. These include in-situ techniques like radiosondes and remote sensing from ground, aircraft and satellites. In Sect. 3.2 six passive remote sensors (for a detailed description see Sect. 2), which operate at different wavelengths and exploit different radiative properties in order to derive IWV are compared to radio-sonde measurements of IWV. In Sect. 3.3 IWV measurements by the satellite based instruments AMSU-B ${ }^{1}$, GOME $^{1}$ and SCIAMACHY ${ }^{1}$ and derived from the GPS ${ }^{1}$ zenith path delay (ZPD) are compared to measurements taken by a ground-based Fourier-transform spectrometer (FTIR). The comparison to the FTIR measurement enforces a largely cloud-free sky as a condition.

The instruments GOME and SCIAMACHY share the technical specifications and the retrieval algorithm. The GOME instrument has a larger footprint. Because of their

\footnotetext{
${ }^{1}$ for the acronyms refer to the instrument description in Sect. 2
}

Published by Copernicus Publications on behalf of the European Geosciences Union. 
similarity they are dealt with together except where difference are noteworthy.

In Sect. 4 data on a detailed basis are shown for two time periods. One time during Polar summer, May 1999, the FTIR has been left running for an extended period of time in order to record a daily cycle. The other time period is during February 2002, when the RAM ${ }^{1}$ and the GPS where running parallel and also measurements of Lunar absorption FTIR are available.

All measurements have been performed in the high Arctic, near the town of $\mathrm{Ny}$ Ålesund, $79^{\circ} \mathrm{N}$.

\section{Instrumentation}

\subsection{The AWIPEV research base $\mathrm{Ny}$ Ålesund}

Ny Ålesund is a village on the Spitsbergen archipelago at $79.9^{\circ} \mathrm{N}, 11.9^{\circ} \mathrm{E}$. The research base AWIPEV is operated jointly by the French Polar institute IPEV ${ }^{2}$ and the German polar institute $\mathrm{AWI}^{3}$. The AWIPEV research base has been recognized as a NDACC ${ }^{4}$ research station. Among several other NDACC instruments (LIDAR ${ }^{5}$, DOAS $^{6}$, radio-sondes) a Bruker 120HR FTIR ${ }^{7}$-spectrometer (1992-1996: Bruker $120 \mathrm{M})$ and the microwave radiometer $\mathrm{RAM}^{8}$ are operated on the AWIPEV station. Regular FTIR measurements in solar and lunar absorption (Notholt et al., 1995) have been conducted since 1993. The RAM started operational measurements in 1996 (Klein et al., 2002). The GPS IWV data set starts in October 2000 (Heise et al., 2009).

\subsubsection{General}

The measurement techniques considered in this work offer different advantages and are subjected to different limitations (compare the instrument descriptions in this section). This makes it necessary to combine time series from different instruments in order to derive a continuous time series (compare Figs. 1 and 2).

The unit used in this work has been chosen to be molec $\mathrm{cm}^{-2}$. This unit is common in spectroscopy. Factors to other common units for IWV are:

$$
\begin{aligned}
& 1 \times 10^{21} \mathrm{molec}^{-2} \hat{=} 0.3 \mathrm{kgm}^{-2} \\
& 1 \mathrm{kgm}^{-2} \hat{=} 0.1 \mathrm{gcm}^{-2} \hat{=} 1 \mathrm{~mm} \text { (liquid water) } .
\end{aligned}
$$

\footnotetext{
${ }^{2}$ Institut Paul Emile Victor, http://www.institut-polaire.fr

${ }^{3}$ Alfred-Wegener-Insitut, http://www.awi.de

${ }^{4}$ Network for Detection of Atmospheric Composition Change, http://www.ndacc.org

${ }^{5}$ Light Detection and Ranging, an active remote sensing technology.

${ }^{6}$ Differential Optical Absorption Spectroscopy

${ }^{7}$ Fourier Transform Infra Red, http://www.iup.uni-bremen.de/ ftir

${ }^{8}$ Radiometer for Atmospheric Measurements, http://www.iup. uni-bremen.de/ram
}

\subsubsection{Radio-sondes at Ny Ålesund}

Apart from launches during campaigns, radio-sondes are launched every day at 11 a.m. UTC from the AWIPEV research base. Before August 2002 the type Vaisala RS-80 was used. It was then replaced by the type Vaisala RS-90 and since September 2003 the type Vaisala RS-92 is used for the regular soundings. The different types have modified humidity sensors in order to address issues described elsewhere (Miloshevich et al., 2009; Vomel et al., 2007, and others). However, an estimation using the formula given by Treffeisen et al. (2007) confirms, that the effects on the total column are less than $0.1 \%$. The subtypes of the radio-sondes have therefore not been used separately in this study.

\subsubsection{FTIR spectrometer at Ny Ålesund}

The FTIR spectrometer at Ny Ålesund is operated in solar or lunar absorption mode whenever weather conditions permit. Due to the measurement principle a clear sight of the illuminating object (Sun or Moon) is necessary during the measurement which takes up to $30 \mathrm{~min}$. During FTIR measurements weather conditions must be stable and the sky must be largely cloud-free. Changes in the optical depth of the atmosphere due to very thin clouds or phenomena like Arctic haze change the signal-to-noise ratio of the measurement. The spectroscopic signatures are much broader (e.g. Ritter et al., 2005) than the signature of gases and do not interfere with the measurement of integrated water vapor.

In the work presented, two micro-windows, $3268 \mathrm{~cm}^{-1}$ to $3273 \mathrm{~cm}^{-1}$ and $3299.5 \mathrm{~cm}^{-1}$ to $3305 \mathrm{~cm}^{-1}$ have been used to derive the IWV. The spectra were recorded using an IndiumAntimonide (InSB) detector cooled with liquid nitrogen and a $\mathrm{CaF}_{2}$ beam splitter. A Signal-to-Noise-Ratio (SNR) of better than 1400 can regularly be obtained for measurement times of about $10 \mathrm{~min}$ in solar absorption spectroscopy. An SNR of about 100 for measurement times of about $30 \mathrm{~min}$ is obtained during winter in lunar absorption mode. The HITRAN database (Rothman et al., 2003, version2k + updates from 2006) has been used to analyze the spectra.

The spectra are inverted using the software SFIT2 (Hase et al., 2004), version 3.93, extended to work with logarithmic state vectors. This has been proven advantageous in the case of water vapor (Schneider et al., 2006). The regularization is done via optimal estimation (Rodgers, 2000), using a simple diagonal auto-covariance matrix. As interfering gases $\mathrm{O}_{3}$ has been retrieved as a profile and $\mathrm{HCN}$ as well as $\mathrm{CH}_{4}$ as columns.

The spectrometer is regularly checked and adjusted using a measurement of a spectrum of a gas cell filled with a known amount of $\mathrm{HBr}$ at defined pressure and temperature. Using this information the influence of the instrument on the spectrum can be derived using the LINEFIT program (Hase et al., 1999). 


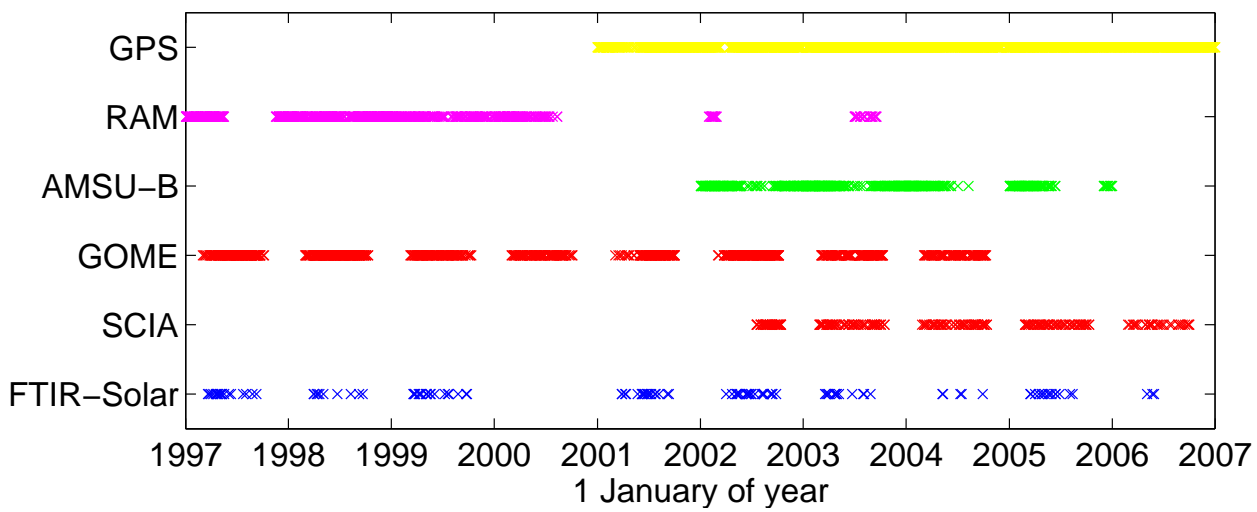

Fig. 1. Matches of the different instruments with radio-sondes during the years 1996 until 2007 for a time criterion of the time of the radio-sonde launch $\pm 2 \mathrm{~h}$. Every cross denotes one match. The radio-sondes are launched every day.

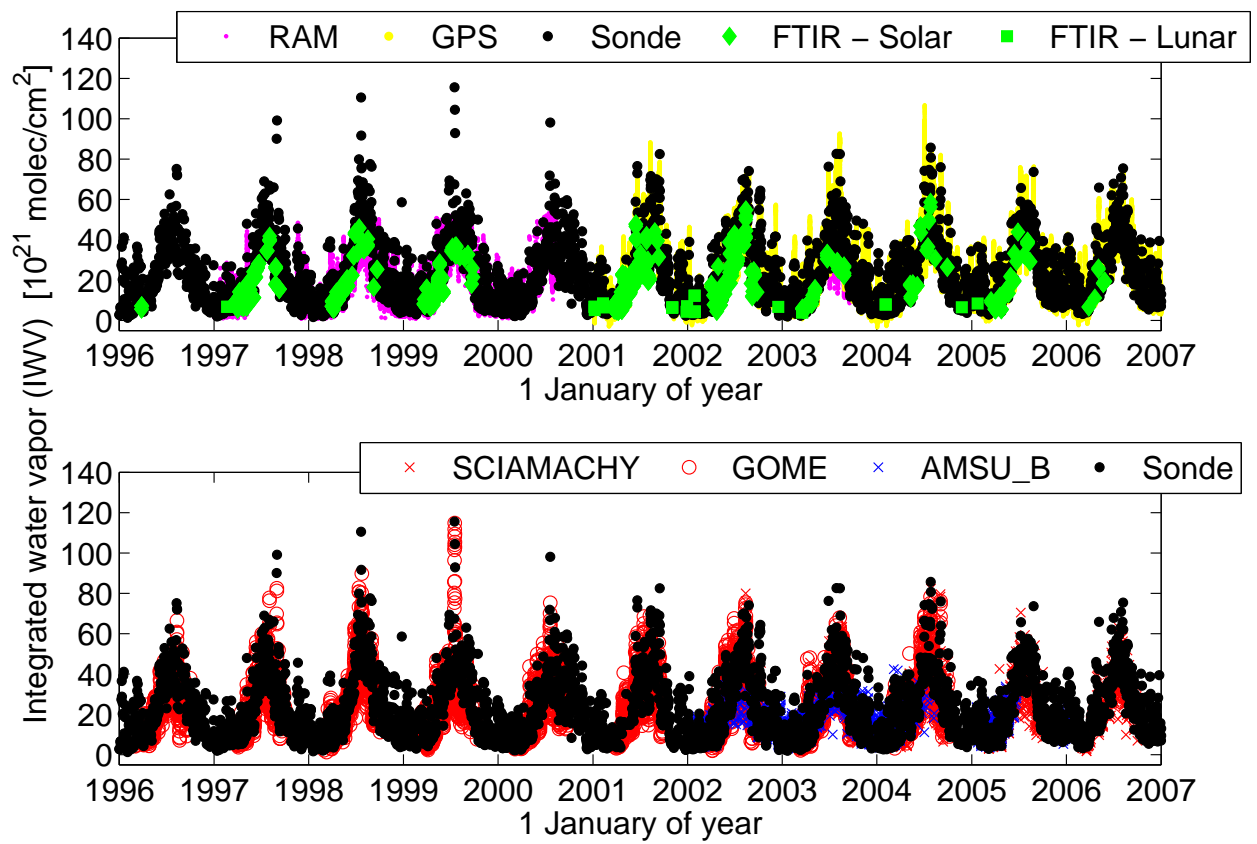

Fig. 2. Measurements of all remote sensors used in this work. All sensors capture the major features of IWV. The advantages and limitations of the remote sensors can readily be observed. While the microwave sensors AMSU-B and RAM are suited best to low IWV observed in polar winter, GOME, SCIAMACHY and FTIR depend on a cloud-free sky. The GPS station operates throughout the year.

\subsubsection{Microwave Spectrometer RAM at Ny Ålesund}

Since 1994 (continuous since 1996) the microwave radiometer RAM measuring the $142 \mathrm{GHz}$ emission of $\mathrm{O}_{3}$ has been operated at the AWIPEV base in Ny Allesund (e.g. Klein et al., 2002). While the main purpose of this instrument is monitoring stratospheric and mesospheric $\mathrm{O}_{3}$, IWV can be derived as a by-product (Wohltmann, 2002).

The spectra are evaluated on an operational basis using the software package QPACK/ARTS (Eriksson et al., 2005; Bühler et al., 2005, ARTS version 1.0). Beside the $\mathrm{O}_{3}$ VMR profile, the tropospheric optical depth $\tau$ is derived during the analysis. This is done by fitting the continuum model MPM93 (Liebe et al., 1993) simultaneously with the $\mathrm{O}_{3}$ spectrum. Under the assumption, that (I) the atmosphere is mainly composed of nitrogen, oxygen and water vapor, (II) the absorption cross sections of water vapor $\alpha_{\mathrm{H}_{2} \mathrm{O}}$ are constant and (III) no scattering occurs, $\tau$ can be used to calculate the IWV, $C_{\mathrm{H}_{2} \mathrm{O}}$, via the empirical formula

$C_{\mathrm{H}_{2} \mathrm{O}}=\frac{\tau-\tau_{\mathrm{O}_{2}}}{\alpha_{\mathrm{H}_{2} \mathrm{O}}}$

The contribution of oxygen to the optical depth, $\tau_{\mathrm{O}_{2}}$, and the absorption cross sections, $\alpha_{\mathrm{H}_{2} \mathrm{O}}$, were determined using the 
radiative transfer model MWMOD (developed at the Universität Kiel; Karstens et al., 1994). For overcast conditions an empirically determined correction following Wohltmann (2002) is applied: The IWV for $100 \%$ relative humidity at all altitude levels is denoted by $C_{\max }$. If the relative humidity is larger than $100 \%$ the IWV $C_{\mathrm{H}_{2} \mathrm{O}}$ is corrected by:

$C_{\text {WET }}=C_{\mathrm{H}_{2} \mathrm{O}}+0.0073 \Delta C^{2}-1.07 \Delta C-2.7384$

where $\Delta C=C_{\mathrm{H}_{2} \mathrm{O}}-C_{\max }$.

After several downtimes due to hardware problems the instrument was taken out of operation due to major failure after 2004 and recommenced work in late 2006. Several changes in hardware and retrieval code ask for a new verification of the data. Those data have not been included in this study.

The RAM measurement represents a mean of about $1 \mathrm{~h}$ measuring time. The time of the measurement is defined as the middle of the integration period.

\subsection{Ground based GPS}

Global Positioning System (GPS) atmospheric remote sensing exploits the influence of the ionosphere and neutral atmosphere constitution on GPS signal propagation. The neutral gas related zenith path delay (ZPD) is routinely estimated in GPS ground station data processing (e.g., Byun and Bar-Server, 2009) and IWV above each station can be estimated from the ZPD humidity induced part ZWD (zenith wet delay). The GPS IWV data used in this study have been derived from the IGS (International GNSS Service) global ZPD dataset (ftp://cddisa.gsfc.nasa.gov/gps/products/ trop_new) applying global ECMWF analysis for ZPD to IWV conversion (Heise et al., 2009). The time resolution is $5 \mathrm{~min}$.

\subsection{GOME onboard ERS-2 and SCIAMACHY on- board ENVISAT}

The Global Ozone Monitoring Experiment (GOME) is part of the payload of the second European Remote Sensing satellite (ERS-2), which was launched in April 1995 (Burrows et al., 1999). GOME measures sunlight transmitted, reflected, and scattered by the Earth's atmosphere or surface in the ultraviolet and visible spectral region (240 to $790 \mathrm{~nm}$ ) at a spectral resolution varying between 0.2 and $0.4 \mathrm{~nm}$. GOME performs earth-shine measurements in nadir viewing geometry with a spatial resolution of about $40 \mathrm{~km} \times 320 \mathrm{~km}$. Operational GOME data are available since June 1995. The GOME instrument is still operating, although since June 2003 with reduced global coverage.

SCIAMACHY (Scanning Imaging Absorption Spectrometer for Atmospheric Chartography) is very similar to GOME but measures in an extended wavelength range (214 to $2386 \mathrm{~nm})$ at moderate spectral resolution $(0.2-1.5 \mathrm{~nm})$. Furthermore, SCIAMACHY measures the earth-shine radiance not only in nadir but also in limb viewing geometry; additionally solar or lunar light transmitted through the atmosphere is observed in occultation. SCIAMACHY was launched in March 2002 onboard ESA's Environmental Satellite ENVISAT. SCIAMACHY operational data products are provided regularly since August 2002. The spatial resolution of SCIAMACHY in nadir mode is a function of wavelength and orbital position, limited on the one hand by the intensity of the incoming radiation and on the other hand by the available data rate. The typical SCIAMACHY ground pixel size in nadir is about $30 \mathrm{~km} \times 60 \mathrm{~km}$. After May 2004 the onboard instrumental setup has been changed to measure even smaller ground pixel sizes in certain situations.

IWV is derived from GOME and SCIAMACHY data with the Air Mass Corrected Differential Optical Absorption Spectroscopy (AMC-DOAS) approach (Noël et al., 2004) using water vapor and molecular oxygen absorption between 688 and $700 \mathrm{~nm}$. The AMC-DOAS method has been applied successfully not only to measurements of GOME and SCIAMACHY but also to measurements of GOME-2 on Metop (Noël et al., 1999, 2008).

\subsection{AMSU-B onboard NOAA-15, NOAA-16 and NOAA-17}

The Advanced Microwave Sounding Unit B (AMSU-B) (Saunders et al., 1995) is part of the Advanced TIROS Operational Vertical Sounder (ATOVS), a collection of sensors flown on the polar orbiting satellites of $\mathrm{NOAA}^{9}$ since the satellite NOAA-15 (operational since December 1998). AMSU-B is a cross-track scanning radiometer with five channels: two window channels (no strong absorption lines) at 89 and $150 \mathrm{GHz}$, and three channels close to the strong water vapour absorption line at $183.3 \mathrm{GHz}$. The imaged strip (swath) is about $2000 \mathrm{~km}$ wide, and the resolution on the ground is between about 15 and $50 \mathrm{~km}$, increasing from the center to the edge of the swath. The outward edge of the swath corresponds to a maximum scanning angle of $48.95^{\circ}$ off-nadir. Since there are about 14 sun-synchronous, nearpolar satellite passes a day, the whole globe is covered once daily, with a lot of overlap in the polar regions. Starting with satellite NOAA-18 (launched 2005, operational since August 2005), AMSU-B has been replaced by the microwave humidity sounder (MHS) which has similar channels, but better performance.

In polar regions, where standard humidity sounding (for which AMSU-B has been designed) does not work, the water vapour column can be retrieved with the method described by Melsheimer and Heygster (2008). It derives the water vapour column from ratios of channel differences, and is independent of daylight and water clouds.

\footnotetext{
${ }^{9}$ National bf Oceanic and Atmospheric Administration of the USA
} 


\subsection{Note: Other instruments measuring IWV at Ny Ålesund}

Lidar. Only very few measurements of IWV by LIDAR exist in Ny Ålesund (oral communication: R. Neuber). The instrument has therefore not been included into this study.

\subsection{A note on errors}

The error bars given for all remote sensing instruments are based on the noise of the measurements. A detailed error analysis has not been attempted in this work, because of the sparse input on uncertainties especially for atmospheric data. Instead, the deviation of the measurements from a common denominator will be used to draw some information about systematic and statistical errors (compare Sect. 3.2).

Typical noise figures (statistical) for the remote sensing instruments are:

SCIAMACHY, GOME. calculated from spectral residuum, less than $10 \%$ (Noël et al., 2004)

$A M S U-B$. calculated from the scatter of all pixels within the radius of $50 \mathrm{~km}$ around $\mathrm{Ny}$ Ålesund. The error is about $10 \%$ (Melsheimer and Heygster, 2008)

FTIR. calculated from the residuum of the spectral fit, about $5 \%$ for the Solar-FTIR and about $20 \%$ for the Lunar-FTIR

$R A M$. calculated from the residuum of the spectral fit, about $10 \%$

GPS. set to $9 \times 10^{21}$ molec $\mathrm{cm}^{-2}$ (Wang et al., 2007)

Those figures do not include systematic errors and depend heavily on the actual conditions during the time of measurement. This work provides an estimate on how the instruments perform compared to a common standard.

\section{Intercomparison of measurements}

An overview over all measurements taken above Ny Ålesund is given by Fig. 2. All sensors capture the seasonal cycle and also reproduce the radio-sonde measurements. It can be seen that for the highest values (IWV of more than $50 \times 10^{21}$ molec $\mathrm{cm}^{-2}$ ), only the radio-sondes, the GPS, the GOME and the SCIAMACHY instrument produce sensible results. While the FTIR would be able to measure such high values, it is restricted to clear sky when such high values of IWV are not observed at Ny Ålesund.

For the comparison, the IWV measurements of one instrument have been chosen to be the standard. The other instruments are compared against this standard. As the common standard, measurements were chosen which are performed during the whole time of the intercomparison. This would make it possible to match time series without overlap to a common series.

The intercomparison has been split into two parts which are distinguished by the standard which is applied. In the first part, Sect. 3.2, IWV values derived from the remote sounding instruments are compared with values obtained from radiosonde launches. The second part, Sect. 3.3, applies the FTIR IWV measurements as the standard. The reason for choosing the second standard is the fact that the FTIR measurements are conducted during clear sky which creates a subset of data for special conditions, clear sky and sun well above horizon.

The position of the measurement of the radio-sonde is difficult to determine, because, depending on wind conditions, the horizontal movement may easily amount to several $100 \mathrm{~km}$ during the ascent.

We assumed, however, that the measurement takes place at Ny Ålesund. This can be justified by keeping in mind that the major part of the IWV is in the lowest few kilometers which are traversed by the radio-sonde in a few minutes with only a few km displacement.

\subsection{Matching criteria}

The radio-sonde, FTIR, RAM and GPS measurements are conducted at the same place, just meters apart from each other. Because of the working principle, however, only the RAM is measuring the same point every time. The flight-path of the radio-sonde is determined by wind, and the viewingpath of the FTIR is determined by the sun and hence the time of day, the GPS ZPD is derived from slant observations determined by the position of the GPS satellites.

Assuming a wind speed of $10 \mathrm{~m} \mathrm{~s}^{-1}$ the radio-sonde travels about $36 \mathrm{~km}$ during $1 \mathrm{~h}$. In $\pm 2 \mathrm{~h}$ the air-masses travel about the radius of the satellite footprints.

A tracing of air-masses has not been conducted because Spitsbergen has mountains rising to $1000 \mathrm{~m}$ altitude and more which are expected to alter the general direction and speed of air masses traversing Spitsbergen. Choosing a matching criterion is therefore a compromise between availability of measurements and the variability of the quantity of interest.

For the satellite measurements an additional, spatial, condition is enforced. For SCIAMACHY and GOME measurements only those soundings were used which cover the location of Ny Ålesund. For AMSU-B, all measurements within a circle of $50 \mathrm{~km}$ radius around $\mathrm{Ny}$ Ålesund have been integrated in order to arrive at one value for IWV.

\section{Summary of the matching criteria}

GROUND-BASED SOLAR FTIR. An FTIR measurement is said to be coincident if it has been recorded within $\pm 2 \mathrm{~h}$ of the radio-sonde launch. Because FTIR measurements are performed during stable weather conditions, this time distance is considered sufficiently small.

GROUND-BASED LUNAR FTIR. For the lunar FTIR measurement a wide time criterion of $\pm 12 \mathrm{~h}$ has to be chosen in order to find any coincidences at all. The wide criterion is reflected in the weak performance compared to the radio-sonde measurement. 


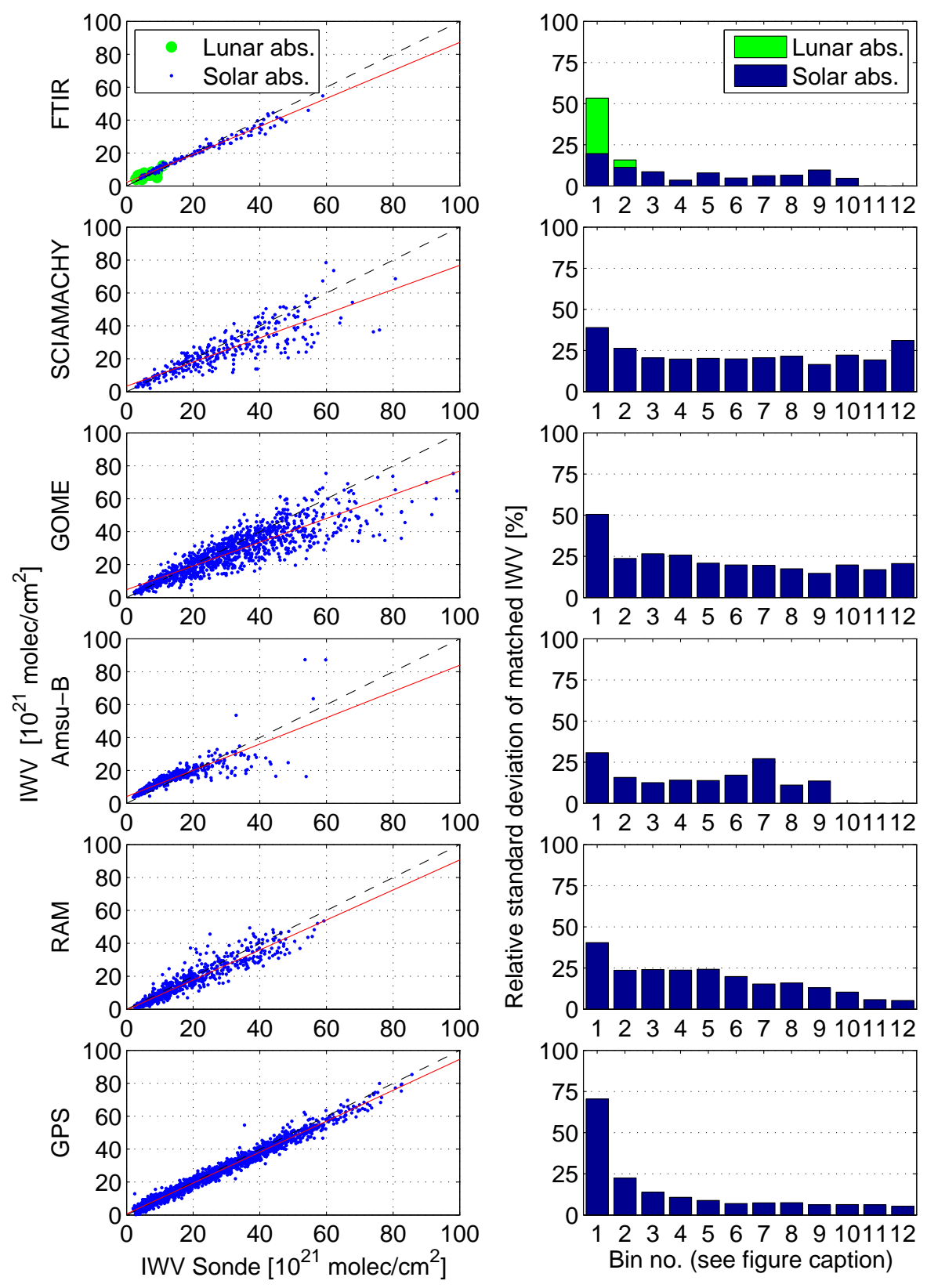

Fig. 3. Comparison of six remote sensing instruments to radio-sonde measurements. The plot on the left shows matching measurements (for matching criteria see Sect. 3.1) of the remote sensing instruments to IWV derived from radio-sondes. The black dashed line is unity, the red solid line a fitted line (compare to Sect. 3.2.1). All values are in $10^{21}$ molec cm${ }^{-2}$. The plot on the right shows relative standard deviations of the remote sensing measurements from the fitted line. The bins are derived from the radio-sonde measurements. They are $5 \times 10^{21}$ molec cm ${ }^{-2}$ wide, starting at 0 . The last bin is $55-60 \times 10^{21}$ molec $\mathrm{cm}^{-2}$. The bars 10 to 12 for the AMSU-B measurements are omitted because of the very few measurements in these bins.

GROUND-BASED MICROWAVE (RAM). For the comparison the measurement closest to the radio-sonde launch, but not further apart than $0.5 \mathrm{~h}$ was chosen.

GROUND-BASED GPS. A GPS measurement is said to be coincident if it has been recorded within $\pm 5 \mathrm{~min}$ of the radio-sonde launch.
SCIAMACHY and GOME. A measurement is said to be coincident if the location of $\mathrm{Ny}$ Ålesund $\left(78.9^{\circ} \mathrm{N}, 11.9^{\circ} \mathrm{E}\right)$ is within the ground pixel and the measurement time is within $\pm 2 \mathrm{~h}$ of the radio-sonde launch.

$A M S U-B$. An AMSU-B measurement is said to be coincident if at least 5 ground pixels are within a radius of $50 \mathrm{~km}$ from the location 
Table 1. Correlation of remote sensing measurements with radio-sonde measurements as outlined in Sect. 3.2.1. The errors given in this table are the errors of the fitted line.

\begin{tabular}{ccccc}
\hline Instrument & $\begin{array}{c}\text { Nr. of } \\
\text { Coincidences }\end{array}$ & Correlation & \multicolumn{2}{c}{ Fitted line } \\
& & & Slope $m$ & $\begin{array}{c}\text { Offset } b \\
{\left[10^{21} \mathrm{molec} \mathrm{c}^{-2}\right]}\end{array}$ \\
\hline FTIR Solar & 136 & 1 & $0.85 \pm 0.01$ & $2.2 \pm 0.3$ \\
FTIR Lunar & 21 & 0.73 & $0.6 \pm 0.1$ & $2.7 \pm 9.2$ \\
SCIAMACHY & 304 & 0.85 & $0.73 \pm 0.03$ & $3.4 \pm 0.8$ \\
GOME & 1130 & 0.883 & $0.72 \pm 0.01$ & $4.8 \pm 0.4$ \\
AMSU-B & 622 & 0.86 & $0.80 \pm 0.02$ & $4.1 \pm 0.2$ \\
RAM & 1043 & 0.95 & $0.91 \pm 0.01$ & $-0.2 \pm 0.2$ \\
GPS & 2199 & 1 & $0.936 \pm 0.003$ & $0.72 \pm 0.08$ \\
\hline
\end{tabular}

of Ny Alesund and the measurement time is within $\pm 2 \mathrm{~h}$ of the radio-sonde launch.

The distribution of the matches for the different instruments are plotted in Fig. 1. The matches for all instruments are well distributed during the time of their respective measurement set.

\subsection{Comparison of radio-sondes and remote sensing in- struments}

\subsubsection{Methodology}

Data derived from remote sensing measurements have been compared to IWV derived from radio-sonde humidity measurements.

In Fig. 3, left panel, the IWV derived from the different remote sensing instruments, $\boldsymbol{c}_{\mathrm{R}}$, versus the IWV derived from radio-sonde measurements, $c_{\mathrm{S}}$, is plotted. A line, with gradient $m$ and offset $b$, has been fitted via linear regression for coincident IWV measurements with index $i$ :

$(m, b)=\arg \min \left(c_{\mathrm{Ri}}-\left(m c_{\mathrm{Si}}+b\right)\right)$

The errors for the remote sensing instruments, $s_{\mathrm{R}}$, have been omitted in the plot, but have been taken into account for the calculation of the errors $s_{m}$ and $s_{b}$ of $m$ and $b$, respectively, by an error propagation calculation. Let $f$ be an arbitrary function and $s_{i}$ the error of the $i$ th argument of $f$, the error propagation is calculated by:

$s_{f}=\sqrt{\sum_{i=1}^{n}\left(\frac{\partial f}{\partial x_{i}} s_{f i}\right)^{2}}$.

The factors $m$ and $b$ are summarized in Table 1. In order to calculate the scatter, the relative standard deviation of the distance of the values $c_{\mathrm{R}}$ from the line (Eq. 3) in the ranges

$$
\begin{aligned}
& {\left[i \times 5 \times 10^{21} \frac{\mathrm{molec}}{\mathrm{cm}^{2}} \ldots(i+1) \times 5 \times 10^{21} \frac{\mathrm{molec}}{\mathrm{cm}^{2}}\right]} \\
& i=0 \ldots 11
\end{aligned}
$$

has been calculated and plotted in Fig. 3, right panel.

Additionally a correlation coefficient $\rho$ has been calculated for each instrument using

$\rho=\frac{\sigma\left(\boldsymbol{c}_{\mathrm{R}}, \boldsymbol{c}_{\mathrm{S}}\right)}{\sqrt{\sigma\left(\boldsymbol{c}_{\mathrm{R}}\right) \sigma\left(\boldsymbol{c}_{\mathrm{S}}\right)}}$

with $\sigma(\boldsymbol{x}, \boldsymbol{Y})$ denoting the covariance of the data sets $\boldsymbol{x}, \boldsymbol{y}$. It is, however, expected that the correlation is very high because of the pronounced seasonal variation of the IWV above Spitsbergen.

\subsubsection{Results}

All remote sensing instruments capture the radio-sonde measurements well but show systematically lower IWV values with respect to the radio-sonde data.

The FTIR in solar absorption mode and the GPS measurements for IWV above $10 \times 10^{21}$ molec $\mathrm{cm}^{-2}$ show very low scatter. In FTIR lunar absorption mode the scatter around the fitted line is very high. This is explained by the rather low SNR compared to the solar absorption measurement and by the loose temporal coincidence criterion ( $12 \mathrm{~h}$ before and after the time of the radio-sonde launch). The FTIR measurements are usually performed during clear sky. It is therefore likely that the bias of the FTIR is caused by a spectroscopic error. For the spectroscopic modelling refer to Boone et al. (2007) and Schneider et al. (2009). If this is relevant for the spectral region used here is part of a further investigation. A simple ad hoc correction of the spectroscopic parameters did not lead to better results.

The ground-based microwave-instrument RAM exhibits a rather large scatter around the mean (fitted line) value. This is expected because the instrument is not designed for measuring IWV. It can still be considered a valuable complement to the ground-based FTIR instrument, because of its ability to measure during the polar night and/or cloudy conditions and the high number of measurements due to its automatic operation.

The GPS is not very much affected by weather conditions and the value of the IWV. Only for very low IWV (smaller 
Table 2. Correlation of four remote sensing instruments with FTIR data. This comparison hints at a cloud-bias for the IWV derived from SCIAMACHY measurements (for details Sect. 3.3.2).

\begin{tabular}{cccc}
\hline Instrument & $\begin{array}{c}\text { Nr. of } \\
\text { Coincidences }\end{array}$ & Slope $b$ & $\begin{array}{c}\text { Fitted line } \\
\text { Offset } m \\
{\left[10^{21} \text { molec cm }^{-2}\right]}\end{array}$ \\
\hline SCIAMACHY & 86 & $1.31 \pm 0.02$ & $-4.4 \pm 0.6$ \\
GOME & 725 & $1.183 \pm 0.01$ & $-2 \pm 0.3$ \\
AMSU-B & 236 & $1.00 \pm 0.03$ & $2.2 \pm 0.5$ \\
GPS & 561 & $1.051 \pm 0.005$ & $-1.4 \pm 0.1$ \\
\hline
\end{tabular}

than $10 \times 10^{21} \mathrm{molec}^{-2}$ ) the scatter becomes very large. This reflects the fact, that the absolute errors in GPS measurements are relatively independent of the IWV value. The GPS measurements is the most complete time series because of its ability to measure under all weather conditions and its independency on light. Only for very low IWV the GPS measurements become inferior to the RAM measurements.

The IWV measured by the GOME and the SCIAMACHY instrument shows a scatter of $20 \%$ around the fitted line. This may be explained by the spatial variation and by interference of clouds. This effect will be investigated further in Sect. 3.3.

The microwave instrument and the AMSU-B instrument operate at very low frequencies in the mm-wavelength range. Scattering by water clouds can largely be neglected. Ice clouds, however, are expected to lead to higher standard deviation in case of the AMSU-B instrument as well as a dry bias (Miao, 1998). The AMSU-B measurements are suited best to cold and dry conditions (Melsheimer and Heygster, 2008). They show a deviation of the IWV from the fitted line of about $20 \%$ to $30 \%$ and become unreliable for more than $30 \times 10^{21}$ molec $\mathrm{cm}^{-2}$ measured by radio-sonde. This finding is in accordance wit the findings of Melsheimer and Heygster (2008).

\subsection{Comparison of IWV derived from FTIR and other remote sensing instruments}

In the study following below, the radio-sonde as standard is replaced by the FTIR measurements. The comparison is therefore restricted to a subset of the data, because of the characteristic of the FTIR, only to measure during clear sight to the sun. This provides a simple check for a systematic bias between clear sky conditions to the overall dataset.

\subsubsection{Methodology}

The IWV values derived from the FTIR measurements, $\boldsymbol{c}_{\mathrm{F}}$, are compared to IWV measurements, $\boldsymbol{c}_{\mathrm{S}}$, from the satellite instruments (see Fig. 4, left panel): GOME onboard ERS2, SCIAMACHY onboard Envisat, AMSU-B onboard NOAA17 , and to the ground based GPS. A linear regression has
Table 3. Correlation of four remote sensing instruments with radiosonde data for coincident measurements with FTIR and radio-sonde measurements.

\begin{tabular}{cccc}
\hline Instrument & $\begin{array}{c}\text { Nr. of } \\
\text { Coincidences }\end{array}$ & Slope & $\begin{array}{c}\text { Fitted line } \\
\text { Offset } \\
{\left[10^{21} \mathrm{molec} \mathrm{cm}^{-2}\right]}\end{array}$ \\
\hline SCIAMACHY & 12 & $1.09 \pm 0.07$ & $-1.3 \pm 2.5$ \\
GOME & 58 & $1.02 \pm 0.03$ & $0.7 \pm 0.1$ \\
AMSU-B & 50 & $0.86 \pm 0.04$ & $4.4 \pm 0.9$ \\
GPS & 85 & $0.90 \pm 0.02$ & $1.1 \pm 0.5$ \\
\hline
\end{tabular}

been performed, this time with the FTIR IWV, $\boldsymbol{c}_{\mathrm{F}}$, as the standard. The index $i$ denotes the number of the coincident pair: $(m, b)=\arg \min \left(c_{\mathrm{Si}}-\left(m c_{\mathrm{Fi}}+b\right)\right)$. The parameters $m$ and $b$ are documented in Table 2. For the second step, matches which are both, within $\pm 2 \mathrm{~h}$ of the FTIR measurement and within $\pm 2 \mathrm{~h}$ of the radio-sonde launch, are compared to the radio-sonde measurements. A FTIR measurement and the radio-sonde launch may therefore be $4 \mathrm{~h}$ apart. This is valid because the FTIR measurements are taken during stable meteorological conditions. Again a linear regression on the subset has been calculated with the radio-sonde data as the standard. The regression for the satellite measurements coinciding with both, the FTIR and the radio-sonde measurement is plotted in Fig. 4, right panel. The results are summarized in Table 3.

\subsubsection{Results}

The SCIAMACHY and the GOME datasets overestimate the IWV with respect to the FTIR measurements. At first sight this is contradictory to the results obtained earlier in Sect. 3.2.2 and Table 1. Comparing the results for FTIR versus radio-sonde and SCIAMACHY versus radio-sonde in Fig. 3, left panel, as well as in Table 1 leads to the expectation that the SCIAMACHY and the GOME measurements underestimate the IWV with respect to the FTIR measurements as well. However, Fig. 4, left panel, and Table 2 show that this is clearly not the case. The IWV derived from SCIAMACHY measurements which match the FTIR measurements and the radio-sonde measurements compare very well to the radiosonde measurements. The comparison, Fig. 4, right panel, and Table 3 hints at the solution: The FTIR measurements are usually performed if the sky is cloud-free. This leads to a special subset of the measurements to be chosen. Only measurements which are taken at very low cloud coverage are picked and compared to the FTIR measurements. Hence, the subset which is chosen for the comparison influences the results of the comparison to a large degree. This leads to the conclusion that cloudy conditions, even if the measurement passes the cloud filter, introduce a severe bias to the SCIAMACHY and the GOME measurements. 

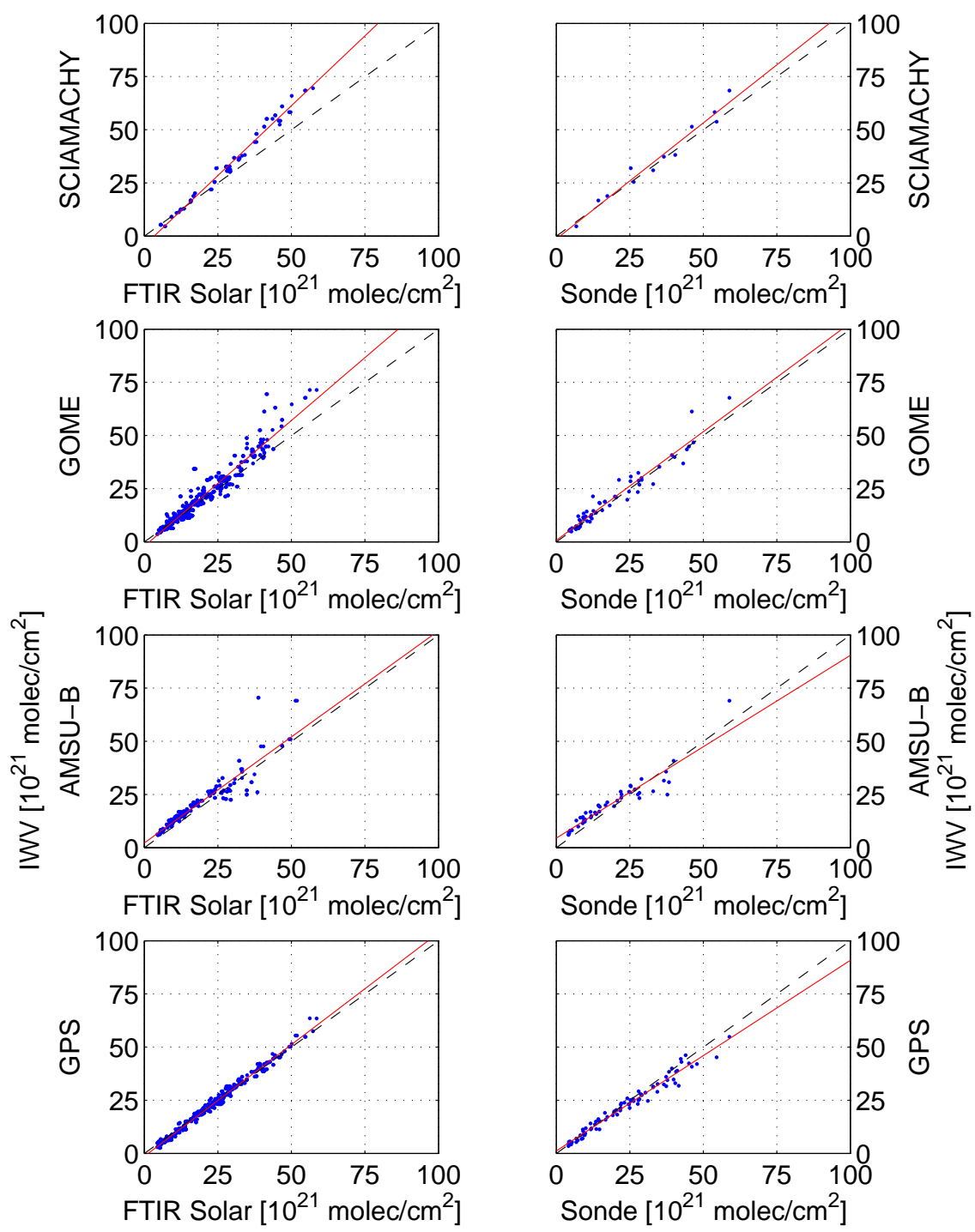

Fig. 4. Comparison of four remote sensing instruments to the results derived from FTIR measurements (left panel). The right panel shows four remote sensing instruments in comparison to radio-sonde measurements which coincide with both, the FTIR and radio-sonde measurements. The black lines denote unity, the red lines are the fitted lines (compare to Sect. 3.2.1).

The AMSU-B and GPS comparisons are consistent with the results obtained in Sect. 3.2.2 and summarized in Table 1. The FTIR, GPS and AMSU-B measurements underestimate the IWV with respect to the radio-sonde measurements in about the same degree. This leads to a good agreement of the FTIR and the AMSU-B measurements. The GPS overestimates the IWV values with respect to the FTIR, which is expected from Table 1. The regression values for AMSU-B versus radio-sonde in Table 1 and Table 3 differ within their standard deviation.

\subsection{Note: Comparison of IWV derived from GPS and other remote sensing instruments}

As a cross check, the GPS measurements of IWV where used as a standard as well. The results where in accordance with the comparison in Sect. 3.2. The only dataset where it could yield additional value is a comparison with IWV from LunarFTIR measurements. The low IWV encountered during measurement conditions for the Lunar-FTIR (the sky has to be cloud free) also means, that the GPS measurements are very noisy, so that the results do not yield much value. 


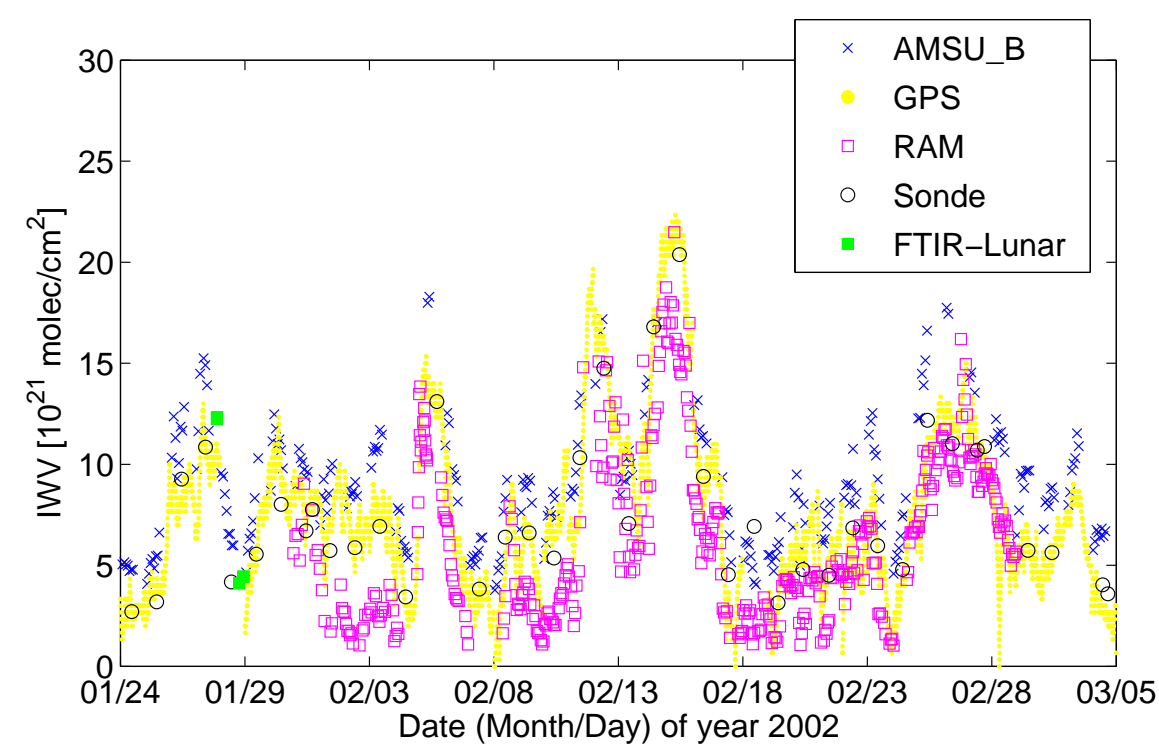

Fig. 5. Time series of AMSU-B, GPS, RAM, lunar-FTIR and radio-sonde measurements of IWV above Ny Ålesund in February 2002.

\section{Detailed IWV comparisons above Ny Ålesund}

In this section two periods where as many instruments as possible worked in parallel are documented. In Fig. 5 a time series of all IWV measurements during February 2002 and in Fig. 6 a time series of RAM and FTIR measurements during May 1999 is shown. The RAM measurements $\boldsymbol{c}_{\text {RAM }}$ have been corrected to yield a slope of 1 when compared to the radio-sonde measurements, i.e. $\boldsymbol{c}_{\mathrm{RAM}}^{\prime}=\left(\boldsymbol{c}_{\mathrm{RAM}}+0.2 \times\right.$ $\left.10^{21}\right) / 0.91$. This has been done in order to remove the systematic error and thus to make the deviations which are described below more visible.

Both plots contain the radio-sonde measurements for comparison. During May 1999 the FTIR has been operated continuously whenever weather conditions permitted. The variation in the FTIR measurements being due to the changing sun zenith angle (Fig. 6) can be ruled out because the RAM measurement shows the same variation. Both figures, 5 and 6 , clearly show the high variance of the IWV above Ny Ålesund.

The solar FTIR and the RAM capture the variation of the IWV well during summer (Fig. 6). The lunar FTIR, RAM, GPS and AMSU-B perform reasonable well during the winter period, compare Fig. 5. For very low IWV values, however, the remote sensing instrument differ considerably. This can be seen best for the periods around 3 February 2002 and around 10 February 2002, where the measurements from the RAM instruments are lower than the measurements from the GPS and the radio-sonde. The AMSU-B measurements are still higher.

\section{Conclusions}

In this work, IWV measured by six remote sensors is compared to IWV derived from radio-sondes. Due to changing weather conditions and the working principle of the sensors the time series of the measurements are only partially overlapping.

The microwave sensors, the $\mathrm{O}_{3}$ sensor RAM and AMSU$\mathrm{B}$, operate best in winter, when the IWV is low. They are partly independent of weather conditions, i.e. light clouds do not distort the measurements beyond recovery. The infrared sensor, FTIR, depends on clear sight to the sun, i.e. no clouds between the instrument and the sun. The optical sensors, SCIAMACHY and GOME, also depends on solar light. Due to the short wave length of the radiation recorded by the SCIAMACHY and the GOME instrument, clouds disturb the measurements considerably. This fact makes it necessary to cloud filter those measurements. The GPS IWV is derived from the ZPD standard product of the IGS global network processing. It measures all year round and is independent of weather.

Measurements from ground-based remote sensors, SolarFTIR and GPS (IWV higher than $10 \times 10^{21}$ molec $\mathrm{cm}^{-2}$ ), are of superior quality. The satellite instruments, AMSU-B, SCIAMACHY and GOME, also perform well if errors are taken into account. For the AMSU-B measurements this includes IWV higher than $30 \times 10^{21} \mathrm{molec}^{-2}$. The higher variance of the satellite-based instruments may be explained by the spatial coverage and by the high variance of IWV. The Lunar-FTIR exhibits a low SNR and very sparse measurements necessiating long coincidence times to enable radiosonde comparisons. Thus, the comparisons with the radiosondes do not yield authoritative results. The comparison 


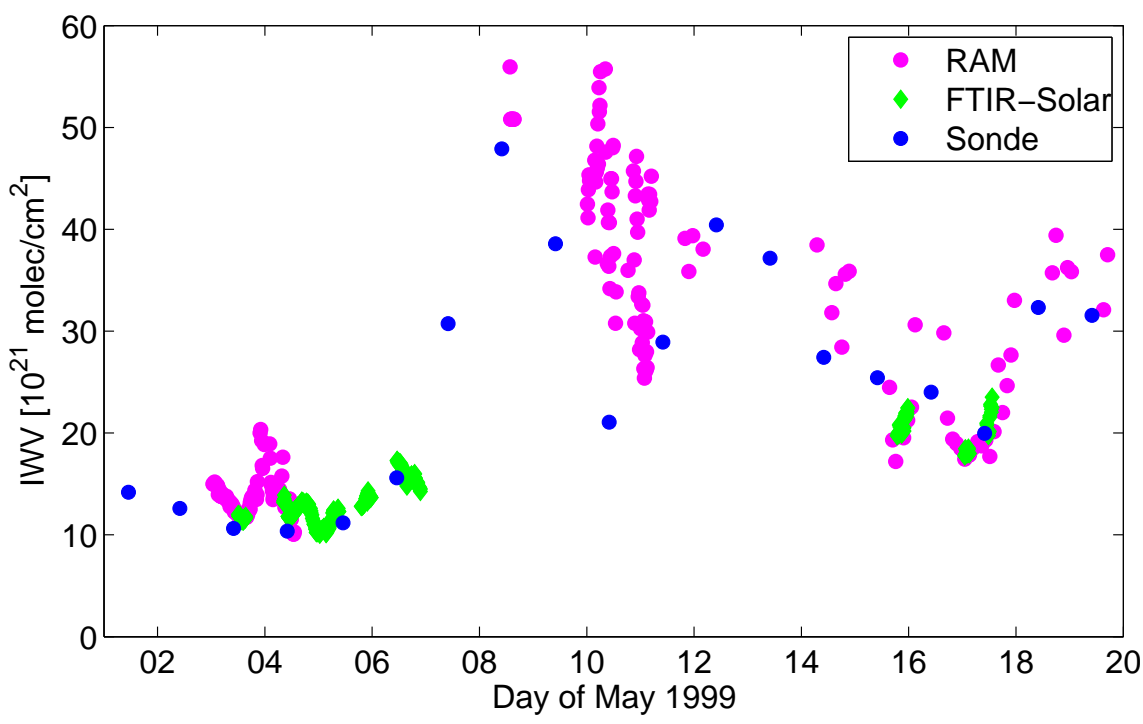

Fig. 6. Time series of RAM, solar-FTIR and radio-sonde measurements above Ny Ålesund in May 1999.

with the GPS data fails because of the high noisiness of the GPS data for low IWV values.

Compared to the IWV derived from radio-sonde measurements, all instruments show a linear behavior, but measure somewhat lower IWV. The remote sensing instruments (SCIAMACHY, GOME, FTIR, AMSU-B, RAM and GPS) exploit different principles in order to derive the IWV.

The IWV values derived from GPS ZPD measurements exhibit high relative scatter for low IWV (smaller than $10 \times 10^{21}$ molec $\mathrm{cm}^{-2}$ ). For lowest IWV (smaller than $5 \times$ $10^{21}$ molec $\mathrm{cm}^{-2}$ ) they are even inferior to the RAM data. This, however, may be improved by application of reliable in situ station pressure observations for ZPD to IWV conversion in place of the time interpolated 6-hourly ECMWF analysis used in this study.

The measurements of the RAM are of fair quality. It has to be taken into account, however, that the RAM is not designed for measuring the IWV but this is a by-product of the $\mathrm{O}_{3}$-measurements. The correlation between radio-sonde and RAM measurements proves that the data can be trusted.

A closer analysis with a cross correlation of the satellite measurements with FTIR and radio-sonde measurements points at an influence of the chosen subset of the SCIAMACHY and GOME measurements. Since the FTIR measures at largely cloud free sky, this subset dependence of the comparison indicates that the influence of clouds on the GOME and SCIAMACHY measurement is not dealt with appropriately by the cloud correction of the GOME and SCIAMACHY measurement algorithm.

From the comparison it becomes evident that there is no single instrument at Ny Alesund, which is sufficient to measure the complete seasonal cycle with high time resolution of several measurements a day at all conditions. A combination of the ground-based sensors is able to cover all sea- sons and ranges of IWV. The FTIR measures in sunlight and clear weather and also high IWV. The Lunar absorption measurements using the FTIR are very sparse and also rather noisy. The gap during night time, cloudy weather conditions and in the polar winter can however be filled using the GPS, except for very low IWV and the microwave data from the ground-based $\mathrm{O}_{3}$-radiometer RAM, which does not work above $50 \times 10^{21}$ molec $\mathrm{cm}^{-2}$ IWV.

Similar conclusions can be drawn for the satellite based instruments SCIAMACHY, GOME and AMSU-B. The strength of the GOME and the SCIAMACHY is the ability to measure high IWV but rely on solar irradiation of the atmosphere and on little interference by clouds. AMSU-B, however, does not rely on external irradiation of the atmosphere and delivers data throughout polar winter.

By taking into account the rapidly changing IWV above Ny Ålesund, it cannot be expected that the comparison of the instruments is much better than in this work. Only the FTIR measurements have little variance. This can be understood by the specifics of the FTIR measurements which can only be performed during clear weather, when the conditions are stable.

Acknowledgements. The staff of the AWIPEV research base carried out the ground-based measurements and the radio-sonde launches.

The AWI Bremerhaven and Potsdam supported this work by providing the logistics to carry out the research at Ny Ålesund.

The GOME and SCIAMACHY data are provided by ESA.

The SCIAMACHY related part has been funded by the DLR, project 50-EE-0010.

The FTIR data acquisition is supported by the TASTE project.

The AMSU-B related parts of this work were supported by the Sixth Framework Programme of the European Union, project DAMOCLES, contract 018509-DAMOCLES. 
The IGS (International GNSS Service) provided GPS ZPD data.

Edited by: A. Hofzumahaus

\section{References}

Boone, C. D., Walker, K. A., and Bernath, P. F.: Speed-dependent Voigt profile for water vapor in infrared remote sensing applications, J. Quant. Spectrosc. Radiat. Transfer, 105, 525-532, 2007.

Bühler, S., Eriksson, P., Kuhn, T., von Engeln, A., and Verdes, C.: ARTS, the atmospheric radiative transfer simulator, J. Quant. Spectrosc. Radiat. Transfer, 91, 65-93, doi:10.1016/j.jqsrt.2004. 05.051, 2005.

Burrows, J. P., Weber, M., Buchwitz, M., Rozanov, V., LadstätterWeißenmayer, A., Richter, A., de Beek, R., Hoogen, R., Bramstedt, K., Eichmann, K.-U., Eisinger, M., and Perner, D.: The Global Ozone Monitoring Experiment (GOME): Mission Concept and First Scientific Results, J. Atmos. Sci., 56, 151-175, 1999.

Eriksson, P., Jiménez, C., and Bühler, S. A.: Qpack, a general tool for instrument simulation and retrieval work, J. Quant. Spectrosc. Radiat. Transfer, 91, 47-64, doi:10.1016/j.jqsrt.2004.05. 050, 2005.

Hase, F., Blumenstock, T., and Paton-Walsh, C.: Analysis of the instrumental line shape of high-resolution Fourier transform IR spectrometers with gas cell measurements and new retrieval software, Appl. Optics, 38, 3417-3422, 1999.

Hase, F., Hannigan, J., Coffey, M., Goldman, A., Höpfner, M., Jones, N., Rinsland, C., and Wood, S.: Intercomparison of retrieval codes used for the analysis of high-resolution, groundbased FTIR measurements, J. Quant. Spectros. Radiat. Transfer, 87, 24-52, doi:10.1016/j.jqsrt.2003.12.008, 2004.

Heise, S., Dick, G., Gendt, G., Schmidt, T., and Wickert, J.: Integrated water vapor from IGS ground-based GPS observations: initial results from a global 5-min data set, Ann. Geophys., 27, 2851-2859, 2009, http://www.ann-geophys.net/27/2851/2009/.

Karstens, U., Simmer, C., and Ruprecht, E.: Remote Sensing of Cloud Liquid Water, Meteorol. Atmos. Phys., 54, 157-171, 1994.

Klein, U., Wohltmann, I., Lindner, K., and Künzi, K. F.: Ozone depletion and chlorine activation in the Arctic winter 1999/2000 observed in Ny-Ålesund, J. Geophys. Res., 107, 8288, doi:10. 1029/2001JD000543, 2002.

Liebe, H. J., Hufford, G. A., and Cotton, M. G.: Propagation modeling of moist air and suspended water/ice particles at frequencies below $1000 \mathrm{GHz}$, in: Proc. AGARD 52nd Spec. Meeting EM Wave Propag. Panel, pp. 3.1-3.10., Palma De Maiorca, Spain, 1993.

Melsheimer, C. and Heygster, G.: Improved retrieval of total water vapor over polar regions from AMSU - B microwave radiometer data, IEEE Trans. Geosci. Remote Sens., 46, 2307-2322, doi: 10.1109/TGRS.2008.918013, 2008.

Miao, J.: Retrieval of Atmospheric Water Vapor Content in Polar Regions Using Space Borne Microwave Radiometry, Ph.D. thesis, Universität Bremen, 1998.

Miloshevich, L. M., Vömel, H., Whiteman, D. N., and Leblanc, T.: Accuracy assessment and correction of Vaisala RS92 radiosonde water vapor measurements, J. Geophys. Res., 114, D11305, doi: 10.1029/2008JD011565, 2009.

Noël, S., Buchwitz, M., Bovensmann, H., Hoogen, R., and Burrows, J. P.: Atmospheric water vapor amounts retrieved from
GOME satellite data, Geophys. Res. Lett., 26, 1841-1844, 1999.

Noël, S., Buchwitz, M., and Burrows, J. P.: First retrieval of global water vapour column amounts from SCIAMACHY measurements, Atmos. Chem. Phys., 4, 111-125, 2004, http://www.atmos-chem-phys.net/4/111/2004/.

Noël, S., Mieruch, S., Bovensmann, H., and Burrows, J. P.: Preliminary results of GOME-2 water vapour retrievals and first applications in polar regions, Atmos. Chem. Phys., 8, 1519-1529, 2008, http://www.atmos-chem-phys.net/8/1519/2008/.

Notholt, J., von der Gathen, P., and Peil, S.: Heterogeneous conversion of HCI and CIONO2 during the Arctic winter 1992/1993 initiating ozone depletion, J. Geophys. Res., 100, 11269-11274, 1995.

Ritter, C., Notholt, J., Fischer, J., and Rathke, C.: Direct thermal radiative forcing of tropospheric aerosol in the Arctic measured by ground based infrared spectrometry, Geophys. Res. Lett., 32, L23816, doi:10.1029/2005GL024331, 2005.

Rodgers, C. D.: Inverse Methods for Atmospheric Sounding, World Scientific Publishing Co. Pte. Ltd., 2000.

Rothman, L., Barbe, A., Benner, D. C., Brown, L., Camy-Peyret, C., Carleer, M., Chance, K., Clerbaux, C., Dana, V., Devic, V., Fayt, A., Flaud, J.-M., Gamache, R., Goldman, A., Jacquemart, D., Jucks, K., Lafferty, W., Mandin, J.-Y., Massie, S., Nemtchinov, V., Newnham, D., Perrin, A., Rinsland, C., Schroeder, J., Smith, K., Smith, M., Tang, K., Toth, R., Auwera, J. V., Varanasi, P., and Yoshino, K.: The HITRAN molecular spectroscopic database: edition of 2000 including updates through 2001, J. Quant. Spectrosc. Radiat. Transfer, 82, 5-44, doi:10.1016/S0022-4073(03) 00146-8, 2003.

Saunders, R., Hewison, T., Stringer, S., and Atkinson, N.: The radiometric characterization of AMSU-B, IEEE Trans. Microwave Theory and Techniques, 43, 760-771, 1995.

Schneider, M., Hase, F., and Blumenstock, T.: Water vapour profiles by ground-based FTIR spectroscopy: study for an optimised retrieval and its validation, Atmos. Chem. Phys., 6, 811-830, 2006, http://www.atmos-chem-phys.net/6/811/2006/.

Schneider, M., Romero, P. M., Hase, F., Blumenstock, T., Cuevas, E., and Ramos, R.: Quality assessment of Izaña's upper-air water vapour measurement techniques: FTIR, Cimel, MFRSR, GPS, and Vaisala RS92, Atmos. Meas. Tech. Discuss., 2, 1625-1662, 2009, http://www.atmos-meas-tech-discuss.net/2/1625/2009/.

Treffeisen, R., Krejci, R., Ström, J., Engvall, A. C., Herber, A., and Thomason, L.: Humidity observations in the Arctic troposphere over Ny-Ålesund, Svalbard based on 15 years of radiosonde data, Atmos. Chem. Phys., 7, 2721-2732, 2007, http://www.atmos-chem-phys.net/7/2721/2007/.

Vomel, H., Selkirk, H., Miloshevich, L., Valverde-Canossa, J., Valdes, J., Kyroe, E., Kivi, R., Stolz, W., Peng, G., and Diaz, J. A.: Radiation dry bias of the vaisala RS92 humidity sensor, J. Atmos. Oceanic Technol., 24, 953-963, doi:\{10.1175/ JTECH2019.1\}, 2007.

Wang, J., Z., L., Dai, A., Van Hove, T., and Van Baelen, J.: A near-global, 2-hourly data set of atmospheric precipitable water from ground-based GPS measurements, J. Geophys. Res., 112, D11107, doi:10.1029/2006JD007529, 2007.

Wohltmann, I.: Ozone depletion, chlorine activation and water vapor observed in Spitsbergen, $\mathrm{PhD}$ thesis, Universität Bremen, 2002. 